\title{
Rotifers (Rotifera) from the inland waters and terrestrial habitats of East Antarctic oases (Enderby Land and Prydz Bay)
}

\author{
Dzmitry A. LUKASHANETS ${ }^{1 *}$, Vasily V. VeZHNAVETS ${ }^{1}$, Natalia N. MAYSAK ${ }^{1}$, \\ Yury H. HIHINIAK ${ }^{1,2}$, Oleg I. BORODIN ${ }^{1,2,3}$, Vladislav Ye. MIAMIN ${ }^{1,2,3}$, Alexey A. GAIDASHOV ${ }^{2}$, \\ Leonid A. NIKITIUK ${ }^{2,4}$ \\ ${ }^{1}$ Scientific and Practical Center for Bioresources of the National Academy of Sciences of Belarus, Akademicheskaya \\ St, 27, Minsk 220072, Belarus \\ ${ }^{2}$ Republican Center for Polar Research, Komsomolskaya St, 16, Minsk 220030, Belarus \\ ${ }^{3}$ Biology Faculty, Belarusian State University, Nezavisimosti Ave, 4, Minsk 220030, Belarus \\ ${ }^{4}$ Surgery Department, Brest Region Hospital, Medicinskaya St, 7, Brest 224027, Belarus \\ *Corresponding author: email: lukashanetzdm@tut.by
}

\begin{abstract}
The paper presents the results of rotiferological studies carried out during the set of the Belarusian Antarctic Expeditions (2007-2017) in East Antarctica (Enderby Land and Prydz Bay). The plankton samples were collected from 52 water bodies (lakes and meltwater ponds), and from terrestrial habitats (lichen fouling, algal mats) from several sites. A total of 20 species were found, 12 of them belonging to Monogononta, 8 - to Bdelloidea. Despite the presence of some cosmopolitan species and Antarctic endemics, the set of species and forms seems to be the firstly noted taxa in East Antarctica.
\end{abstract}

Key words: Bdelloidea, Monogononta, diversity, Antarctica, Thala Hills, Larsemann Hills

\section{INTRODUCTION}

The history of rotifers studies in Antarctica originates in 1900s and is related to registrations of numerous bdelloids (subclass Bdelloidea) from unidentified taxa, which were allocated by F. Richters $(1904,1907)$ from moss samples. Murray (1910) carried out the pioneer work which contained the information of the newly described species of Antarctic rotifers. There we can gather information about 16 species (12 of them are bdelloids and four are monogononts).

From the beginning of $20^{\text {th }}$ century, the rotifer species list of Antarctic biodiversity realm (i.e. including Maritime Antarctica and Subantarctica) has been increased significantly (Sudzuki 1964; 1979; 1988; Dartnall 1983 and many others). The number of known species is now 153 (Fontaneto et al. 2015b). All these studies were carried out in different types of habitats, both aquatic (inland lakes with different degrees of salinity, meltwater ponds, maritime coastal) and terrestrial (mosses, lichens, and soil). Species composition varies according to type of the habitat, with monogonont species (subclass Monogononta) mostly in planktonic samples and bdelloids primarily in terrestrial habitats. Most of the obtained data are summarized in the set of taxonomy and faunal bulletins (Dartnall 1983, De Paggi \& Koste 1984, Sudzuki 1988, Adams et al. 2006; Velasco-Castrillon et al. 2014a and others). Perhaps, the most comprehensive dataset was used in the article of Fontaneto et al. cited above (2015b) which is devoted to analysis of rotifer biogeography patterns in Antarctica. But the survey area is still small in comparison to habitats available on the continent (Convey 2010; Convey et al. 2014), thus we may assume that the rotifer species list in Antarctica will be much bigger. 


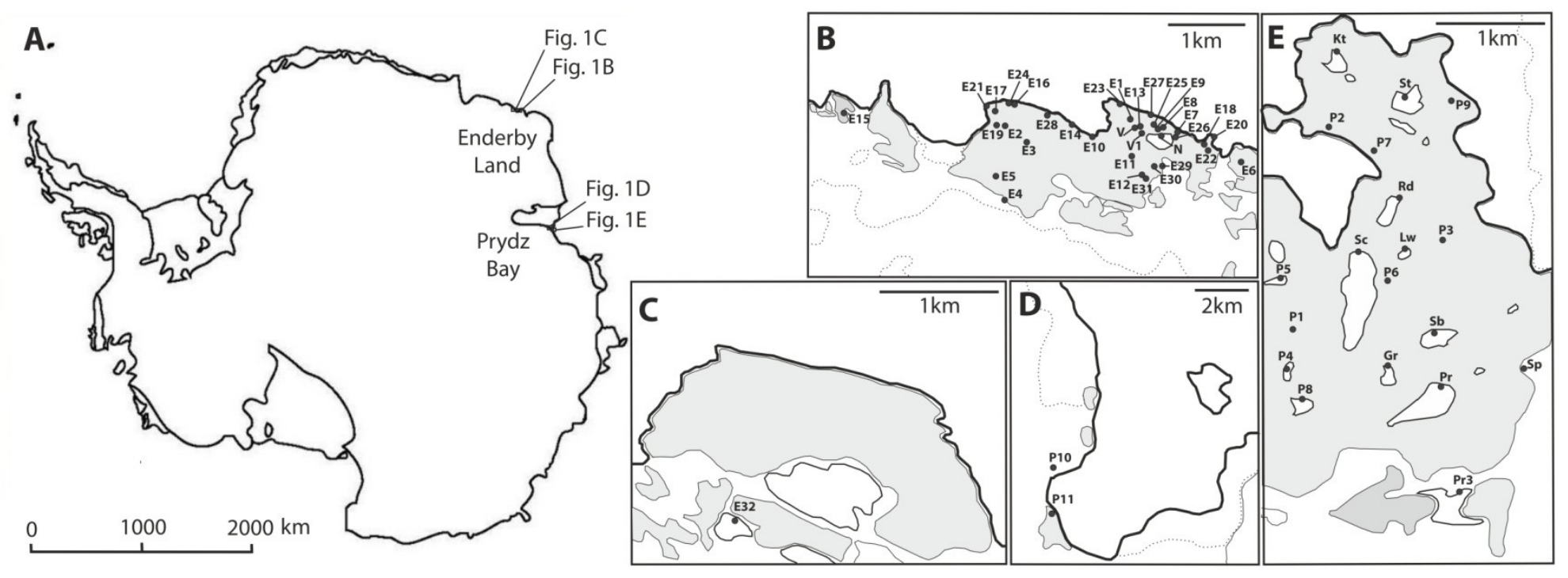

Fig. 1. Study sites. A - The location of study areas on the map of Antarctica; $\mathbf{B}$ - The area of 'Vecherniaya Mount' field base (Thala Hills oasis); C - The area of 'Molodiozhnaya' field base (Thala Hills oasis); D - The area of 'Druzhniy-4' field base; E - The area of 'Progress' station (Larsemann Hills oasis); On 1B-E the areas without permanent ice cover are in gray. 
In accordance with the most recent data related to significant rotifers endemism in Antarctica (Velasco-Castrillon et al. 2014b; Iakovenko et al. 2015) we believe that the researching of these invertebrates at the icebound continent could lead to results of large importance in understanding of distribution, biogeography and evolution of the phylum Rotifera. In that way basic primary studies of the rotifer diversity in different localities of Antarctica are still absolutely needed.

This article contains the results of the research carried out during seasonal Belarusian Antarctic Expeditions (further referred as BAE) collecting both plankton samples and terrestrial substrates in East Antarctica. The analysis of the obtained data concerns both taxonomy and diversity of rotifers (especially those concerning poorly investigated bdelloids) as well as their biogeography.

\section{MATERIALS AND METHODS}

\section{Study sites}

All studies were carried out in two regions of East Antarctica: Enderby Land and Prydz Bay. The location of the sampling sites (water bodies and the places of terrestrial substrates picking) is shown on the map (Fig. 1).

Enderby Land. The area around two neighboring Antarctic field bases - 'Vecherniaya Mount' (Belarus) and 'Molodiozhnaya' (Russian Federation) in Thala Hills oasis was investigated. We sampled 33 water bodies within the territory, three of which are being large freshwater lakes and the rest are being small unnamed lakes and meltwater ponds (Fig. 2). In addition to plankton samples, algal and lichen mats from terrestrial habitats were also taken.
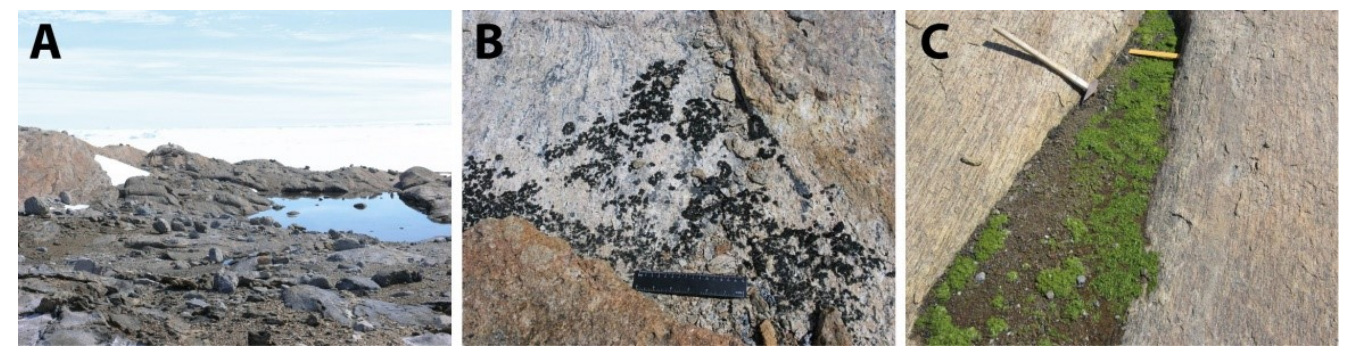

Fig. 2. Examples of studied habitats. A - Meltwater pond. B - Lichen fouling. C-Algae Prasiola crispa.

Prydz Bay. 19 water bodies were sampled in the area of the Russian station 'Progress' (Larsemann Hills oasis), 10 of which were denominated relatively large freshwater lakes. One bottom organic sediment sample was collected from a completely dried meltwater pond. Several samples (plankton from one lake and lichen fouling) were collected near the field base 'Druzhniy-4' and included to the selected data from Prydz Bay area (see Table 1).

\section{Data collection}

All field investigations were carried out during the 1st, 2nd, 4th, 5th, 6th, 8th and 9th BAE, which were implemented in austral summer seasons in the following order: 2007/2008; 2008/2009; 2010/2011; 2012/2013; 2013/2014; 2015/2016; 2016/2017.

Samples of zooplankton were collected with the use of standard hydrobiological procedures (Schwoebler 1972 and others) with plankton nets (diameter of mesh is $45 \mu \mathrm{m}$ or $20 \mu \mathrm{m}$ ). Samples were collected with the use of different methodologies corresponding to aims of particular collection (depending on aims of an expedition). In the present analysis we showed data revealed from both qualitative and quantitative samples (40, 50, 150, 200 and 400 1); in the second case a 
recalculation in absolute density indexes (individuals in $100 \mathrm{l}^{-1}$ ) for each species found in a sample was made. The material was preserved in $6 \%$ formaldehyde solution. The samples of terrestrial substrates (lichens and algal maths) were collected on rocks and lakeshores by handpicking. These samples were not preserved to keep alive bdelloid rotifers that cannot be identified after formalin or ethanol fixation.

All samples were delivered at the Scientific and Practical Center for Bioresources of the National Academy of Sciences of Belarus (further referred as SPC for Bioresourses) Minsk city, Belarus.

Table 1. List of samples examined.

\begin{tabular}{|c|c|c|c|c|}
\hline \multicolumn{5}{|c|}{ Studies in Enderby Land } \\
\hline Sign & Type & Habitat & Coordinates & Date of sampling \\
\hline $\mathrm{V}$ & Plankton & Lake Verhnee & $67.655639^{0} \mathrm{~S} 46.152056^{0} \mathrm{E}$ & Jan 2008 \\
\hline$V^{\prime}$ & Plankton & Lake Verhnee & $67.655694^{0} \mathrm{~S} 46.152056^{\circ} \mathrm{E}$ & Jan 2011 \\
\hline$V^{\prime \prime}$ & Plankton & Lake Verhnee & $67.655694^{0} \mathrm{~S} 46.152056^{\circ} \mathrm{E}$ & Dec 2012, Jan 2013 \\
\hline V”, & Plankton & Lake Verhnee & $67.655667^{0} \mathrm{~S} 46.152056^{0} \mathrm{E}$ & Jan 2016 \\
\hline V1 & Plankton & Lake Verhnee-1 & $67.656278^{\circ} \mathrm{S} 46.154944^{0} \mathrm{E}$ & Dec 2012, Jan 2013 \\
\hline $\mathrm{N}$ & Plankton & Lake Nizhnee & $67.656361^{0} \mathrm{~S} 46.160528^{\circ} \mathrm{E}$ & Jan 2008 \\
\hline $\mathrm{N}^{\prime \prime}$ & Plankton & Lake Nizhnee & $67.656222^{0} \mathrm{~S} 46.160444^{0} \mathrm{E}$ & Jan 2016 \\
\hline E1 & Plankton & Lake (innom.) & $67.655056^{0} \mathrm{~S} 46.151917^{0} \mathrm{E}$ & Dec 2012, Jan 2013 \\
\hline E2 & Plankton & Lake (innom.) & $67.654417^{0} \mathrm{~S} 46.110250^{\circ} \mathrm{E}$ & Jan 2013 \\
\hline E3 & Plankton & Lake (innom.) & $67.655028^{\circ} \mathrm{S} 46.117417^{0} \mathrm{E}$ & Jan 2013 \\
\hline $\mathrm{E} 4$ & Plankton & Meltwater pond & $67.661889^{\circ} \mathrm{S} 46.109556^{\circ} \mathrm{E}$ & Jan 2013 \\
\hline E5 & Plankton & Meltwater pond & $67.659639^{\circ} \mathrm{S} 46.107167^{\circ} \mathrm{E}$ & Jan 2013 \\
\hline E6 & Plankton & Meltwater pond & $67.659694^{\circ} \mathrm{S} 46.185472^{\circ} \mathrm{E}$ & Jan 2013 \\
\hline E7 & Plankton & Meltwater pond & $67.655722^{\circ} \mathrm{S} 46.161278^{\circ} \mathrm{E}$ & Feb 2013 \\
\hline E8 & Plankton & Meltwater pond & $67.655722^{0} \mathrm{~S} 46.160056^{0} \mathrm{E}$ & Feb 2013 \\
\hline E9 & Plankton & Meltwater pond & $67.655472^{\circ} \mathrm{S} 46.156722^{\circ} \mathrm{E}$ & Feb 2013 \\
\hline E10 & Plankton & Meltwater pond & $67.656861^{\circ} \mathrm{S} 46.140722^{\circ} \mathrm{E}$ & Feb 2013 \\
\hline E11 & Plankton & Meltwater pond & $67.659167^{0} \mathrm{~S} 46.151750^{\circ} \mathrm{E}$ & Feb 2013 \\
\hline E12 & Plankton & Meltwater pond & $67.659972^{\circ} \mathrm{S} 46.154583^{\circ} \mathrm{E}$ & Feb 2013 \\
\hline E13 & Plankton & Lake (innom.) & $67.655667^{0} \mathrm{~S} 46.151683^{\circ} \mathrm{E}$ & Jan 2009 \\
\hline E14 & Plankton & Lake (innom.) & $67.654850^{\circ} \mathrm{S} 46.132950^{\circ} \mathrm{E}$ & Jan 2009 \\
\hline E15 & Plankton & Lake (innom.) & $67.653633^{0} \mathrm{~S} 46.059733^{\circ} \mathrm{E}$ & Jan 2009 \\
\hline E16 & Plankton & Lake (innom.) & $67.651717^{0} \mathrm{~S} 46.112767^{\circ} \mathrm{E}$ & Jan 2009 \\
\hline E17 & Plankton & Meltwater pond & $67.652783^{\circ} \mathrm{S} 46.107000^{\circ} \mathrm{E}$ & Jan 2009 \\
\hline E18 & Plankton & Lake (innom.) & $67.656850^{\circ} \mathrm{S} 46.175167^{\circ} \mathrm{E}$ & Jan 2009 \\
\hline E19 & Plankton & Lake (innom.) & $67.654717^{0} \mathrm{~S} 46.110283^{\circ} \mathrm{E}$ & Feb 2009 \\
\hline E20 & Plankton & Meltwater pond & $67.654467^{\circ} \mathrm{S} 46.176983^{\circ} \mathrm{E}$ & Jan 2009 \\
\hline E21 & Plankton & Meltwater pond & $67.652400^{\circ} \mathrm{S} 46.105983^{\circ} \mathrm{E}$ & Jan 2009 \\
\hline E22 & Plankton & Lake (innom.) & $67.656850^{\circ} \mathrm{S} 46.175167^{\circ} \mathrm{E}$ & Jan 2009 \\
\hline E23 & Plankton & Meltwater pond & $67.652200^{\circ} \mathrm{S} 46.147533^{\circ} \mathrm{E}$ & Jan 2009 \\
\hline E24 & Plankton & Lake (innom.) & $67.651867^{0} \mathrm{~S} 46.113617^{0} \mathrm{E}$ & Jan 2009 \\
\hline E25 & Plankton & Lake (innom.) & $67.655433^{\circ} \mathrm{S} 46.156350^{\circ} \mathrm{E}$ & Feb 2009 \\
\hline E26 & Plankton & Lake (innom.) & $67.653917^{0} \mathrm{~S} 46.156783^{\circ} \mathrm{E}$ & III 2009 \\
\hline E27 & Plankton & Lake (innom.) & $67.657050^{\circ} \mathrm{S} 46.161950^{\circ} \mathrm{E}$ & III 2009 \\
\hline E28 & Lichen & Fouling on stone & $67.653567^{\circ} \mathrm{S} 46.123683^{\circ} \mathrm{E}$ & Jan 2009 \\
\hline E29 & Algal math & Lake shore & $67.658776^{0} \mathrm{~S} 46.159734^{0} \mathrm{E}$ & Jan 2013 \\
\hline E30 & Plankton & Meltwater pond & $67.658444^{0} \mathrm{~S} 46.157833^{\circ} \mathrm{E}$ & Jan 2016 \\
\hline E31 & Plankton & Meltwater pond & $67.659944^{\circ} \mathrm{S} 46.154389^{\circ} \mathrm{E}$ & Jan 2016 \\
\hline E32 & Plankton & Lake (innom.) & $67.667434^{0} \mathrm{~S} 45.852946^{\circ} \mathrm{E}$ & Jan 2008 \\
\hline \multicolumn{5}{|c|}{ Studies in Prydz Bay } \\
\hline Sign & Type & Habitat & Coordinates & Date of sampling \\
\hline $\mathrm{Gr}$ & Plankton & Lake Gornoe & $69.398733^{0} \mathrm{~S} 76.376533^{0} \mathrm{E}$ & Jan 2014 \\
\hline $\mathrm{Kt}$ & Plankton & Lake Kitayskoe & $69.377533^{0} \mathrm{~S} 76.375917^{0} \mathrm{E}$ & Jan 2014 \\
\hline Lw & Plankton & Lake Law & $69.388900^{\circ} \mathrm{S} 76.382250^{\circ} \mathrm{E}$ & Jan 2014 \\
\hline $\operatorname{Pr}$ & Plankton & Lake Progress & $69.400450^{\circ} \mathrm{S} 76.407717^{0} \mathrm{E}$ & Jan 2014 \\
\hline
\end{tabular}




\begin{tabular}{|c|c|c|c|c|}
\hline Pr3 & Plankton & Lake Progress-3 & $69.412067^{0} \mathrm{~S} 76.403033^{0} \mathrm{E}$ & Jan 2014 \\
\hline $\mathrm{Rd}$ & Plankton & Lake Reid & $69.386833^{\circ} \mathrm{S} 76.376833^{\circ} \mathrm{E}$ & Jan 2014 \\
\hline $\mathrm{Sp}$ & Plankton & Lake Serpe & $69.400000^{0} \mathrm{~S} 76.408967^{0} \mathrm{E}$ & Jan 2014 \\
\hline $\mathrm{Sb}$ & Plankton & Lake Sibthorpe & $69.395650^{\circ} \mathrm{S} 76.398283^{\circ} \mathrm{E}$ & Jan 2014 \\
\hline $\mathrm{Sc}$ & Plankton & Lake Scandrett & $69.389717^{0} \mathrm{~S} 76.369533^{\circ} \mathrm{E}$ & Jan 2014 \\
\hline St & Plankton & Lake Stepped & $69.375000^{\circ} \mathrm{S} 76.385000^{\circ} \mathrm{E}$ & Jan 2014 \\
\hline St' & Plankton & Lake Stepped & $69.375000^{\circ} \mathrm{S} 76.385000^{\circ} \mathrm{E}$ & Feb 2011 \\
\hline P1 & Plankton & Lake (innom.) & $69.396906^{0} \mathrm{~S} 76.355166^{0} \mathrm{E}$ & Jan 2011 \\
\hline $\mathrm{P} 2$ & Plankton & Lake (innom.) & $69.378638^{0} \mathrm{~S} 76.365493^{\circ} \mathrm{E}$ & Jan 2011 \\
\hline P3 & Plankton & Lake (innom.) & $69.388991^{0} \mathrm{~S} 76.389154^{0} \mathrm{E}$ & Jan 2011 \\
\hline P4 & Plankton & Lake (innom.) & $69.398946^{0} \mathrm{~S} 76.354684^{0} \mathrm{E}$ & Jan 2011 \\
\hline P5 & Plankton & Lake (innom.) & $69.391896^{\circ} \mathrm{S} 76.350283^{\circ} \mathrm{E}$ & Jan 2011 \\
\hline P6 & Plankton & Lake (innom.) & $69.392361^{0} \mathrm{~S} 76.376957^{0} \mathrm{E}$ & Jan 2011 \\
\hline P7 & Plankton & Lake (innom.) & $69.380373^{\circ} \mathrm{S} 76.373553^{0} \mathrm{E}$ & Jan 2011 \\
\hline P8 & Plankton & Lake (innom.) & $69.402023^{0} \mathrm{~S} 76.358659^{0} \mathrm{E}$ & Jan 2011 \\
\hline P9 & Dry organic sediments & Dry bottom of the pond & $69.375539^{0} \mathrm{~S} 76.394536^{0} \mathrm{E}$ & Feb 2017 \\
\hline P10 & Plankton & Lake (innom.) & $69.730995^{\circ} \mathrm{S} 73.707651^{0} \mathrm{E}$ & Jan 2011 \\
\hline P11 & Lichen & Fouling on stone & $69.741359^{0} \mathrm{~S} 73.709155^{\circ} \mathrm{E}$ & Jan 2011 \\
\hline
\end{tabular}

\section{Sample processing and species identification}

Plankton processing included a detailed examination of an extra concentrated sample (from entire sample volume to approximately $100 \mathrm{ml}$ ) in a counting chamber or Petri dish with the use of a binocular microscope (Leica MZ12 and others) to find rotifers. A similar procedure was done in case of terrestrial substrates processing: searching of individuals was carried out in a piece of substrate placed into the Petri dish with distilled water.

The specimens found in samples (fixated in plankton samples and alive in terrestrial substrates) later were moved on a slide and examined under magnification not less than $\times 40$ $(\times 100$ and $\times 200$ were preferred) using the light microscopes (Micros, Jenaval and others). Periodically chlorine-containing reagents were used to dissolve soft body of a rotifer and to make details of trophi (sclerotized jaws) visible.

Microphotographs obtained by various cameras (Microscope VISION, AxioCAM) served as confirmative data and also for morphometric analysis which was performed according to recently developed method (Iakovenko et al. 2013). There were measured in $\mu \mathrm{m}$ : total length (TL), greatest trunk width (BW), head length (HL), collar width (HW), rump length (RL), largest rump width (RW), foot length (FL), foot maximal width (FW), ramus length (RaL), neck length (NL), spur length (SL), spur-bearing pseudosegment width (SSW). The ratio (\%) of these dimensions was used for body proportion assessment.

The main keys and notes we applied for species identification were: Nogrady et al. 1995; De Smet and Poirrot 1997; Kutikova 1970; Kutikova 1991; Kutikova 2005; Donner 1965; Shiel 1995; Dartnall and Hollowday 1985. We used recent article focused on the taxonomy revise of Antarctic bdelloids (Iakovenko et al. 2015) and some other articles which include species descriptions (Meksuwan et al. 2013).

All samples, specimens and the bank of photo data are stored in collections SPC for Bioresourses.

\section{RESULTS}

All rotifer specimens found in Antarctic water bodies and terrestrial substrates during our studies belong to 20 identified species (including several valid infraspecific taxa).

The list of all species is ordered according to taxonomy used in Rotifer World Catalog (Jersabek \& Leitner 2013). We give the original names, synonyms and the appropriate references 
to sources and the corresponding identification keys. Our taxonomic notes are provided to clarify some ambiguities in the identification of species ${ }^{1}$.

Kingdom Animalia Linnaeus, 1758

Subkingdom Eumetazoa Buetschli, 1910

Superphylum Platyzoa Cavalier-Smith, 1998

Phylum Rotifera Cuvier, 1910

Class Eurotatoria De Ridder, 1957

Subclass Bdelloidea Hudson \& Gosse, 1886

Order Adinetida Melone \& Ricci, 1995

Family Adinetidae Bryce, 1910

Genus Adineta Hudson \& Gosse, 1886

\section{Adineta editae Iakovenko, 2015}

Adineta editae Iakovenko 2015: 15.

Adineta gracilis Janson, 1893: 77 - Dartnall \& Hollowday 1985: 30, Donner 1965: 274, Kutikova 2005: 271

Notes. Based on the external morphology, we firstly considered these Adineta representatives with rostrum lamella not divided into lobes and without filamentous bristles as Adineta gracilis, which seemed quite fair. Despite the fact that the species was already recorded in Antarctica (Murray 1910; Sudzuki 1964; Sohlenius et al. 1996; Sohlenius \& Bostrőm 2005), its taxonomy has recently become the subject of lively discussion. Especially after Iakovenko et al. (2015), who, using mitochondrial DNA sequencing, morphometry and analysis of masticatory apparatus, suggested to revise most of all Antarctic Adineta gracilis recorded in earlier taxonomic works as was the case with $A$. editae Iakovenko, 2015. After the publication of the above quoted work and after the consultation with its author (N.S. Iakovenko) our identification of Adineta gracilis has changed, and we reconsidered the species as Adineta editae. The main features, that settled our diagnosis and allowed to distinguish $A$. editae from $A$. gracilis were the following traits: (1) larger size (more than $300 \mu \mathrm{m}$ ), (2) relatively massive and wide trunk, (3) absence of the head elongation in the direction from the distal to the proximal.

\section{Adineta cf. grandis Murray, 1910}

(Fig. 3A)

Adineta grandis Murray, 1910: 51 - Dartnall \& Hollowday 1985: 33, Donner 1965: 273, Kutikova 2005: 275, Iakovenko et al. 2015: 20

Notes. The following traits of $A$. grandis we considered as specific for the species: (1) vivacity and (2) very large sizes of the body (up to $500 \mu \mathrm{m}$ and even higher) and trophi (up to $30 \mu \mathrm{m}$ ). Hundreds of such individuals (up to approximately 800 per $100 \mathrm{mg}$ of substrate) that had other features of $A$. grandis i.e. colored in orange, reddish or brownish, relatively short foot, rostrum lamella divided in two lobes (Fig. 3A1-4) were found in dry organic sediments. It is worth noting that the obtained body measurements for $A$. grandis strongly coincide with data

\footnotetext{
${ }^{1}$ Due to rotifer's microscopic size, dormant stage and existing of cryptic species the taxonomic studies in this animal group are extremely complicated. Some doubts may be possibly explained by molecular methods and the detail analysis of the microstructure of trophi (Fontaneto et al. 2009).
} 


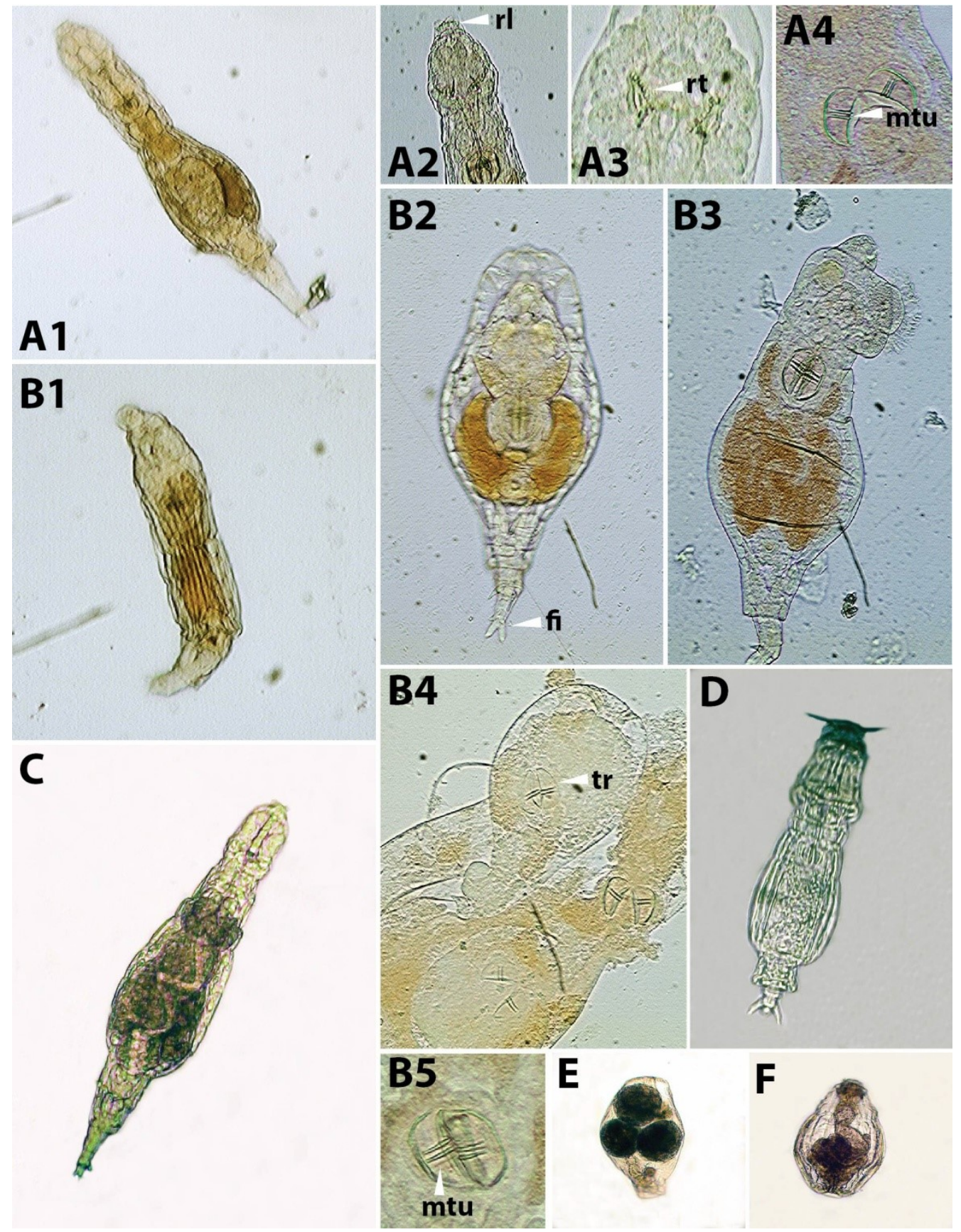

Fig. 3. Rotifers of Bdelloidea subclass. A - Adineta $c f$. grandis Murray, 1910: A1 - dorsal view, A2 - head, A3 fragment of head of the pressed specimen, A4 - masticatory apparatus. B - Philodina gregaria Murray, 1910: B1 lateral view, $\mathbf{B 2}$ - dorsal view of the pressed specimen, $\mathbf{B 3}$ - dorsal view of the pressed specimen with semi-spread corona, B4 - three embryos from one maternal specimen, B5 - masticatory apparatus. C - Adineta cf. vaga vaga (Davis, 1873). D - Adineta steineri Bartoš, 1951. E, F - Unidentified bdelloid rotifers in contracted shape (examples); $\mathbf{m t u}$ - major teeth in unci; rl - rostrum lamella; $\mathbf{r t ~ - ~ r a k e ~ t e e t h ; ~ f i ~ - ~ f i n g e r s ; ~} \mathbf{t r}$ - trophi. 
from a completely different location of Antarctica - Cape Royds (type locality) and Antarctic Peninsula. Absolutely all ratio indices were within the range indicated for $A$. grandis from other regions (Table 2). All this supports the unambiguity of this identification; still the cryptic species A. fontanetoi Iakovenko et al., 2015 should not be excluded. This species has the same external morphology as $A$. grandis and the differences may be found only at the molecular level or in slightly larger sizes of trophi. In this way, we have no choice except to consider this species as A. cf. grandis.

\title{
Adineta steineri Bartoš, 1951
}

(Fig. 3D)

Adineta steineri Bartoš 1951: 478 - Donner 1965: 270, Kutikova 2005: 271

Notes. The species is easily identifiable because of long bristles on the trunk (Fig. 3D). $A$. steineri is widely distributed outside Antarctica, but was found at the continent, too (Sohlenius et al. 1996; Sohlenius \& Bostrőm 2005).

\section{Adineta cf. vaga vaga (Davis, 1873)}

(Fig. 3C)

Callidina vaga Davis 1873: 201

Adineta vaga - Donner 1965: 295, Kutikova 2005: 275

Notes. This morphospecies was identified as typical form of the Adineta vaga (Davis, 1873), which is the very common oviparous species characterized by rostrum with two lobes bearing not bristles but only very short cilia (Fig. 3C). Iakovenko et al. (2015) pointed that newly described $A$. emsliei Iakovenko et al., 2015 strongly resembles $A$. vaga. However, the registered morphospecies (1) was colourless, not bright orange or brown; (2) has triangular simple spurs, not needle-formed based on bulbs. These diagnostic peculiarities approached the observed rotifers much closer to $A$. vaga and distingushed them from $A$. emsliei. However, the morphometric analysis shows the similarity with $A$. emsliei in basic proportions of the head, body and foot. Also the rump of the species is rather long but narrower (Table 2). Obviously, for more correct comparison, more data (measured individuals) are needed.

\section{Adineta cf. vaga minor Bryce, 1893}

Adineta vaga minor Bryce 1893: 146 - Donner 1965: 274, Kutikova 2005: 275.

Notes. As with Adineta cf. vaga vaga, the identification of another form of the species was ambiguous. Due to the smaller sizes $(250-300 \mu \mathrm{m})$, the 'subtle' exterior and smooth transition from the posterior end of the trunk to the preanal segment, the morphospecies was considered $A$. vaga minor Bryce, 1893.

\author{
Order Philodinida Melone \& Ricci, 1995 \\ Family Philodinidae Harring, 1913 \\ Genus Macrotrachela Milne, 1886
}

Macrotrachela kallosoma (Schulte, 1954)

Mniobia kallosoma Schulte 1954: 606

Macrotrachela kallosoma - Donner 1965: 151, Kutikova 2005: 142 
Genus Philodina Ehrenberg, 1830

\section{Philodina alata Murray, 1910}

Philodina alata Murray 1910: 46 - Donner 1965: 207, Kutikova 1991: 93, 95, Kutikova 2005: 207

Notes. All individuals in plankton samples are contracted but could be identified by two characteristic lateral appendages.

\section{Philodina gregaria Murray, 1910}

(Fig. 3B)

Philodina gregaria Murray, 1910: 42 - Dartnall \& Hollowday 1985: 33, Donner 1965: 202, Kutikova 2005: 221

Table 2. Body dimensions (Mean \pm SD) and proportions (Min-Max) of the bdelloid species: comparison of data obtained with literature data (cases of maximum coincidence are in bold)

\begin{tabular}{|c|c|c|c|c|}
\hline \multirow[b]{2}{*}{ Parameter } & \multicolumn{2}{|c|}{ Adineta grandis } & \multicolumn{2}{|c|}{ Adineta vaga / Adineta emsliei } \\
\hline & Present study & Iakovenko et al., 2015 & Present study & Iakovenko et al., 2015 \\
\hline \multicolumn{5}{|l|}{ Measures, $\mu \mathrm{m}$} \\
\hline TL & $465 \pm 22$ & $414 \pm 61$ & 310 & $294 \pm 44$ \\
\hline BW & $108 \pm 2$ & $94 \pm 22$ & 71 & $69 \pm 15$ \\
\hline HL & $68 \pm 5$ & $70 \pm 9$ & 46.5 & $49 \pm 8$ \\
\hline HW & $58 \pm 4$ & $56 \pm 7$ & 37.2 & $39+5$ \\
\hline NL & $72 \pm 5$ & $82 \pm 19$ & 40 & $50 \pm 10$ \\
\hline RL & $57 \pm 2$ & $52 \pm 10$ & 53 & $41 \pm 8$ \\
\hline RW & $47 \pm 2$ & $46 \pm 10$ & 36.5 & $35 \pm 7$ \\
\hline FL & $51 \pm 4$ & $52 \pm 12$ & 43.5 & $36 \pm 5$ \\
\hline SL & 13 & $11 \pm 2$ & - & $7 \pm 1$ \\
\hline SSW & 16 & $13 \pm 2$ & - & $9 \pm 1$ \\
\hline $\mathrm{RaL}$ & $27.8 \pm 1.5$ & $25.4 \pm 1$ & 16.5 & $15.7 \pm 2$ \\
\hline \multicolumn{5}{|l|}{ Proportions, \% } \\
\hline $\mathrm{HL} / \mathrm{TL}$ & 13 & $13-19$ & 15 & $13-18$ \\
\hline HW / HL & $77-94$ & $66-97$ & 80 & 71-94 \\
\hline NL / TL & $15-16$ & $11-27$ & 13 & $14-21$ \\
\hline $\mathrm{BW} / \mathrm{TL}$ & $22-24$ & $16-31$ & 23 & $19-27$ \\
\hline RL / TL & $11-12$ & $7-16$ & 17 & $11-16$ \\
\hline RW / RL & $83-84$ & $74-103$ & 69 & $74-98$ \\
\hline $\mathrm{FL} / \mathrm{TL}$ & $10-11$ & $6-15$ & 14 & $10-16$ \\
\hline $\mathrm{FW} / \mathrm{FL}$ & $50-52$ & $40-56$ & - & $29-45$ \\
\hline SL / SSW & 81 & $60-98$ & - & $60-94$ \\
\hline
\end{tabular}

Subclass Monogononta Plate, 1889

Order Collothecaceae Harring, 1913

Family Collothecidae Harring, 1913

Genus Collotheca Harring, 1913

\section{Collotheca ornata (Ehrenberg, 1832)}

(Fig. 4B)

Froscularia ornata Ehrenberg 1832: 146.

Collotheca ornata - Kutikova 1970: 688, Meksuwan et al. 2013: 13, Shiel 1995: 33 
Notes. Despite the fact that $C$. ornata cornuta is considered more typical of Antarctica (Dougherty \& Harris 1963, Dartnall 1995, 2000 and others), we considered the collected individuals to be representative of the typical species $C$. ornata due to the lack of a specific worm-like appendage on the spinal blade.

\author{
Order Ploima Hudson\&Gosse, 1886 \\ Family Brachionidae Ehrenberg, 1838 \\ Genus Kellicottia Ahlstrom, 1938
}

Kellicottia longispina (Kellicott, 1879)

Anuraea longispina Kellicott 1879: 19

Kellicottia longispina - Kutikova 1970: 613

Genus Keratella Bory de St. Vincent, 1822

Keratella cochlearis (Gosse, 1851)

Anuraea cochlearis Gosse 1851: 202

Keratella cochlearis - Kutikova 1970: 600, Shiel 1995: 70

\title{
Keratella tecta (Gosse, 1851)
}

Anuraea tecta Gosse 1851: 202

Keratella cochlearis tecta - Kutikova 1970: 603

Keratella tecta - Shiel 1995: 70

Genus Notholca Gosse, 1886

Notholca verae Kutikova, 1958

(Fig. 4E)

Notholca verae Kutikova 1958: 45 - Kutikova 1970: 618, 623, Kutikova 1991: 94

Family Dicranophoridae Harring, 1913

Genus Encentrum Ehrenberg, 1838

Encentrum saundersiae (Hudson, 1885)

Taphrocampa saundersiae Hudson 1885: 614

Encentrum (Parencentrum) saundersiae - Kutikova 1970: 410

Encentrum saundersiae - De Smet \& Pourriot 1997: 164

Family Epiphanidae Harring, 1913

Genus Epiphanes Ehrenberg, 1832

Epiphanes senta (Müller, 1773)

(Fig. 4C)

Vorticella senta Müller 1773: 109

Epiphanes senta - Dartnall \& Hollowday 1985: 6, Kutikova 1970: 507, Shiel 1995: 62 

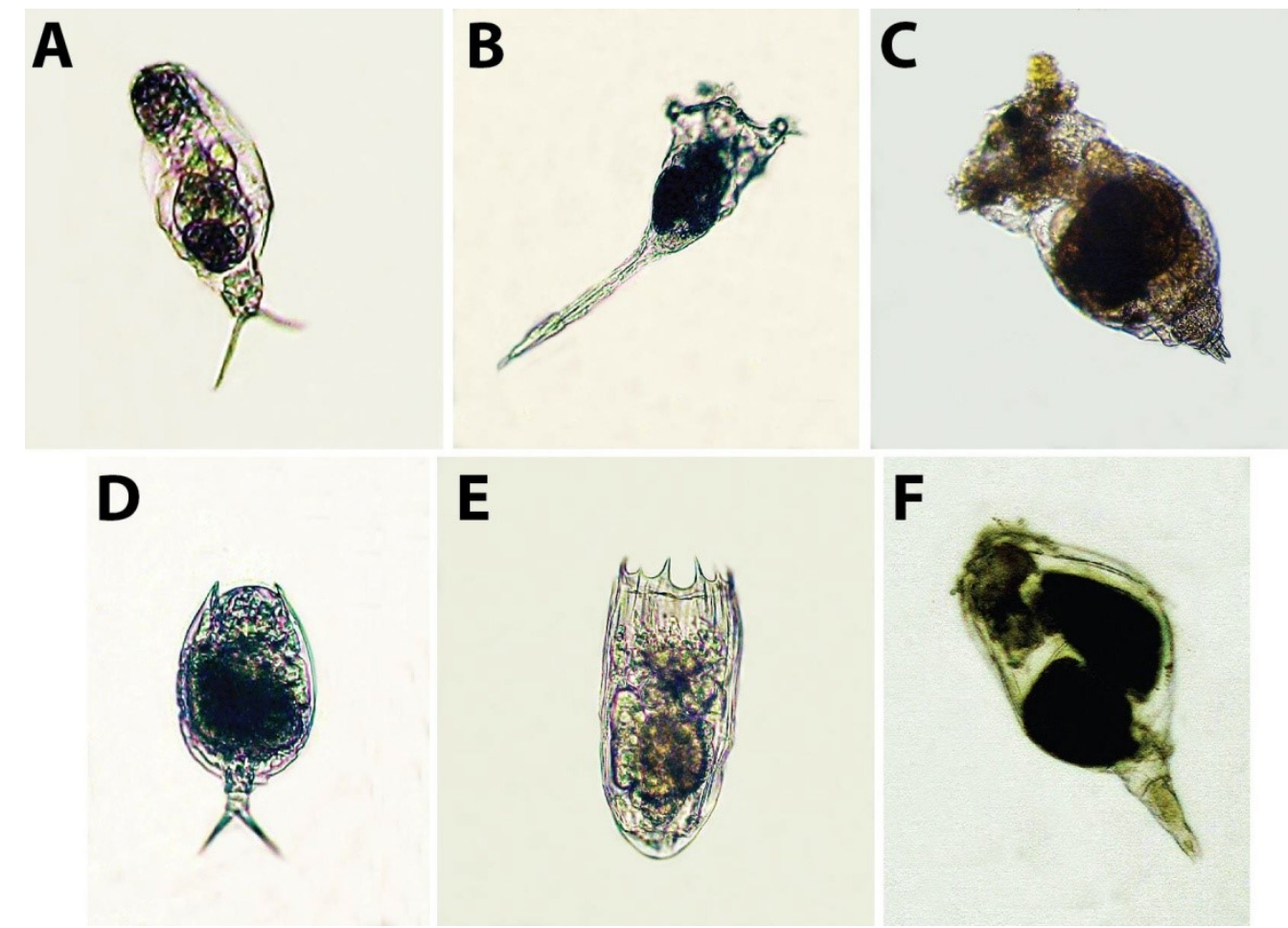

Fig. 4. Rotifers of Monogononta subclass. A - Cephalodella forficata (Ehrenberg, 1832); B - Collotheca ornata (Ehrenberg, 1832); C - Epiphanes senta (Müller, 1773); D - Lepadella patella (Müller, 1773); E - Notholca verae Kutikova, 1958; F - Resticula gelida (Harring \& Myers, 1924).

Genus Rhinoglena Ehrenberg, 1853

\section{Rhinoglena cf. frontalis Ehrenberg, 1853}

Rhinoglena frontalis Ehrenberg 1853: 190 - Kutikova 1970: 504, Shiel 1995: 63

Notes. The identification raised some doubts because other representatives of the genus Rhinoglena fertoeensis (Varga, 1929) and recently described Rh. kutikovae De Smet, 2008 - also inhabit East Antarctica, Bunger Hills oasis (Kutikova 1958, 1991, De Smet \& Gibson 2008). Especially, we did not observe trophi of the collected Rhinoglena individuals; hence, we should determine the species as 'Rhinoglena cf. frontalis'.

Family Lepadellidae Harring, 1913

Genus Lepadella Bory de St. Vincent, 1826

\section{Lepadella patella (Müller, 1773)}

(Fig. 4D)

Brachionus patella Müller 1773: 341

Lepadella patella - Kutikova 1970: 550, Kutikova 1991: 93 
Family Notommatidae Hudson \& Gosse, 1886

Genus Cephalodella Bory de St. Vincent, 1826

Cephalodella forficata (Ehrenberg, 1832)

(Fig. 4A)

Notommata forficata Ehrenberg 1832: 134

Cephalodella forficata - Dartnall \& Hollowday 1985: 16, Kutikova 1970: 262, Nogrady et al. 1995: 76

\section{Cephalodella sterea (Gosse, 1887)}

Furcularia sterea Gosse 1887: 864

Cephalodella sterea - Kutikova 1970: 238, Kutikova 1991: 87, 93, Nogrady et al. 1995: 127

Genus Resticula Harring \& Myers, 1924

Resticula gelida (Harring \& Myers, 1924)

(Fig. 4F)

Eosphora gelida Harring \& Myers 1922: 642

Resticula gelida - Dartnall \& Hollowday 1985: 21, Kutikova 1970: 288, Nogrady et al. 1995: 213

\section{DISCUSSION}

The rotifer diversity in analyzed plankton samples can be characterized as poor: 12 monogonont species and one valid bdelloid species (Philodina alata Murray, 1910) both in lakes and meltwater ponds (Table 3). The maximal numbers of species (if consider also gen. sp.) per water body are 7 and 5 (both for Lake Steppet, Larsemann Hills), but almost all other water bodies contain only one or two identified species (Table 3). According to some published data (Dartnall 1995, Ellis-Evans et al. 1998) inland waters of Antarctica are very sparsely populated with zooplankton community including rotifers. Some authors (Sharov et al. 2015) even assert the fragmentariness and 'lopped' character of trophic webs in the pelagic of Antarctic water bodies. Thus, the observed scarcity of rotifer species recorded during the present study seems to be quite expected. Additionally, rotifers were absent in several meltwater ponds and lakes in both examined regions; these water bodies were not included to the diversity analysis (neither shown in Table 3).

Regarding the bdelloids found in four distinct habitats, 7 species were recorded which is comparable with the whole number of planktonic rotifers (13) from dozens of sampled water bodies. On the other hand, numerous contracted bdelloids were found in plankton samples, too (Table 3). Somewhere (lakes Verhnee-1, Progress, Progress-3, Serpe, Sibthorpe, E2, E3, E16, meltwater ponds E4, E5, E6, E7, E20, and others) bdelloids consisted $100 \%$ from all rotifers in the plankton. As already mentioned above, in many cases contracted bdelloid individuals were identified as Philodina alata. The identification to the level of genus of some non-active specimens with typical features for Bdelloidea (ramate mastax, foot with two spurs, etc.) was possible due to an adhesive plate instead of toes that are typical to the genus Mniobia (Table 3). Other planktonic bdelloids remained unidentified. Additionally, in both aquatic and terrestrial systems some another rotifers with the typical Adineta morphology were found (flattered body, oval head wider than neck, very short rostrum, corona looks like the simple ciliate field on the ventral side of head, thin foot etc.). Number of U-shaped teeth on the grasping apparatus of these rotifers was not established as well as presence / absence of long bristles and the shape of lamella on the rostrum. This species is shown in Table 3 as Adineta sp. 
Table 3. Species diversity with relative abundance (\%) of rotifers in samples collected in Eastern Antarctic oases

\begin{tabular}{|c|c|c|c|c|c|c|c|c|c|c|c|c|c|c|c|c|c|c|c|c|}
\hline \multicolumn{21}{|l|}{ Studies in Enderby Land } \\
\hline Taxon & $\mathbf{V}$ & $\mathbf{V}^{\prime}$ & $\mathbf{V}^{\prime \prime}$ & V', & V1 & $\mathbf{N}$ & $\mathbf{N}^{\prime}$ & N"' & E1 & $\mathbf{E 2}$ & $\mathbf{E 3}$ & $\mathbf{E 4}$ & $\mathbf{E 5}$ & E6 & E7 & $\mathbf{E 8}$ & E9 & E10 & E11 & E12 \\
\hline \multicolumn{21}{|l|}{$\begin{array}{l}\text { SUBLASS BDELLOIDEA } \\
\text { FAMILY ADINETIDAE }\end{array}$} \\
\hline $\begin{array}{l}\text { FAMILY ADINETIDAE } \\
\text { Adineta } \text { cf. grandis Murray, } 1910\end{array}$ & & & & & & & & & & & & & & & & & & & & \\
\hline \\
\hline \multicolumn{21}{|l|}{ Adineta steineri Bartoš, 1951} \\
\hline \multicolumn{21}{|l|}{ Adineta cf. vaga (Davis, 1873) } \\
\hline \multicolumn{21}{|l|}{ Adineta $\mathrm{cf}$. vaga minor (Bryce, 1893) } \\
\hline \multicolumn{21}{|l|}{ Adineta sp. } \\
\hline \multicolumn{21}{|l|}{ FAMILY PHILODINIDAE } \\
\hline \multicolumn{21}{|l|}{ Macrotrachela kallosoma (Schulte, 1954) } \\
\hline \multicolumn{21}{|l|}{ Mniobia sp. } \\
\hline Philodina alata Murray, 1910 & & & 9 & & & & 50 & & & & & & & 17 & & $<1$ & & 3 & 100 & 100 \\
\hline \multicolumn{21}{|l|}{ Philodina gregaria Murray, 1910} \\
\hline Bdelloidea sp. & 53 & & 89 & 96 & 100 & 91 & 50 & 100 & 97 & 100 & 100 & 100 & 100 & 83 & 100 & 98 & 100 & 96 & & \\
\hline \multicolumn{21}{|l|}{ SUBCLASS MONOGONONTA } \\
\hline \multicolumn{21}{|l|}{ FAMILY COLLOTHECIDAE } \\
\hline \multirow{2}{*}{\multicolumn{21}{|c|}{$\begin{array}{l}\text { Collotheca ornata (Ehrenberg, 1832) } \\
\text { FAMILY BRACHIONIDAE }\end{array}$}} \\
\hline \multirow{2}{*}{\multicolumn{20}{|c|}{ FAMILY BRACHIONIDAE }} & \\
\hline Kellicottia longispina (Kellicott, 1879) & 33 & & & & & & & & & & & & & & & & & & & \\
\hline Keratella cochlearis (Gosse, 1851) & & & & & & 9 & & & & & & & & & & & & & & \\
\hline Keratella tecta $(\mathrm{Gosse}, 1851)$ & 13 & & & & & & & & & & & & & & & & & & & \\
\hline \multicolumn{21}{|l|}{ Notholca verae Kutikova, 1958} \\
\hline \multirow{2}{*}{\multicolumn{21}{|c|}{$\begin{array}{l}\text { FAMILY DICRANOPHORIDAE } \\
\text { Encentrum saundersiae (Hudson, 1885) }\end{array}$}} \\
\hline \multicolumn{10}{|l|}{ Encentrum saundersiae (Hudson, 1885) } & & & & & & & & & & & \\
\hline \multicolumn{21}{|l|}{ FAMILY EPIPHANIDAE } \\
\hline Epiphanes senta (Müller, 1773) & & & $<1$ & & & & & & $<1$ & & & & & & & & & & & \\
\hline \multicolumn{21}{|l|}{ Rhinoglena cf. frontalis Ehrenberg, 1853} \\
\hline FAMILY LEPADELLIDAE & & & & & & & & & & & & & & & & & & & & \\
\hline Lepadella patella (Müller, 1773) & & 100 & $<1$ & 4 & & & & & 3 & & & & & & & & & & & \\
\hline FAMILY NOTOMMATIDAE & & & & & & & & & & & & & & & & & & & & \\
\hline Cephalodella forficata (Ehrenberg, 1832) & & & & & & & & & & & & & & & & & & & & \\
\hline Cephalodella sterea (Gosse, 1887) & & & & & & & & & & & & & & & & $<1$ & & & & \\
\hline Resticula gelida (Harring \& Myers, 1922) & & & & & & & & & & & & & & & & & & & & \\
\hline TOTAL NUMBER OF TAXA & 3 & 1 & 4 & 2 & 1 & 2 & 2 & 1 & 3 & 1 & 1 & 1 & 1 & 2 & 1 & 3 & 1 & 2 & 1 & 1 \\
\hline TOTAL ABUNDANCE, IND·100 L ${ }^{-1}$ & - & - & 94 & 14 & 4.5 & - & $<1$ & 1 & 1063 & 9.5 & 4 & $<1$ & $<1$ & 3 & 11 & 89 & 83 & 29 & 11 & 6 \\
\hline
\end{tabular}


Studies in Enderby Land (continuation)

\begin{tabular}{|c|c|c|c|c|c|c|c|c|c|c|c|c|c|c|c|c|c|c|c|c|}
\hline Taxon & E13 & E14 & E15 & E16 & E17 & E18 & E19 & E20 & E21 & E22 & E23 & E24 & E25 & E26 & E27 & E28 & E29 & E30 & E31 & E32 \\
\hline \multirow{2}{*}{\multicolumn{21}{|c|}{ SUBLASS BDELLOIDEA }} \\
\hline \multirow{2}{*}{\multicolumn{21}{|c|}{$\begin{array}{l}\text { FAMILY ADINETIDAE } \\
\text { Adineta } \text { cf. grandis Murray, } 1910\end{array}$}} \\
\hline & & & & & & & & & & & & & & & & & & & & \\
\hline Adineta editae Iakovenko, 2015 & & & & & & & & & & & & & & & & & 9 & & & \\
\hline Adineta steineri Bartoš, 1951 & & & & & & & & & & & & & & & & 100 & & & & \\
\hline Adineta cf. vaga (Davis, 1873) & & & & & & & & & & & & & & & & & 48 & & & \\
\hline Adineta cf. vaga minor (Bryce, 1893) & & & & & & & & & & & & & & & & & 14 & & & \\
\hline Adineta sp. & & 20 & & & & & & & & 100 & & & & & & & 19 & & & \\
\hline \multicolumn{21}{|l|}{ FAMILY PHILODINIDAE } \\
\hline Mniobia sp. & & & & & & & & & & & & & & & & & 5 & & & \\
\hline \multicolumn{21}{|l|}{ Philodina alata Murray, 1910} \\
\hline \multicolumn{21}{|l|}{ Philodina gregaria Murray, 1910} \\
\hline Bdelloidea sp. & 86 & 80 & 100 & 100 & 100 & 98 & 100 & 100 & 99 & & 100 & 99 & 75 & 100 & 100 & & & 100 & 100 & 67 \\
\hline \multirow{2}{*}{\multicolumn{21}{|c|}{ SUBCLASS MONOGONONTA }} \\
\hline \multicolumn{13}{|l|}{ FAMILY COLLOTHECIDAE } & & & & & & & & \\
\hline Collotheca ornata (Ehrenberg, 1832) & & & & & & & & & & & & & & & & & & & & 8 \\
\hline \multicolumn{21}{|l|}{ FAMILY BRACHIONIDAE } \\
\hline Kellicottia longispina (Kellicott, 1879) & & & & & & & & & & & & & & & & & & & & 25 \\
\hline Keratella cochlearis (Gosse, 1851) & 7 & & & & & & & & & & & & 25 & & & & & & & \\
\hline \multicolumn{21}{|l|}{ FAMILY DICRANOPHORIDAE } \\
\hline Encentrum saundersiae (Hudson, 1885) & & & & & & & & & $<1$ & & & & & & & & & & & \\
\hline \multicolumn{21}{|l|}{ FAMILY EPIPHANIDAE } \\
\hline \multicolumn{21}{|l|}{ Epiphanes senta (Müller, 1773) } \\
\hline Rhinoglena cf. frontalis Ehrenberg, 1853 & 7 & & & & & 2 & & & & & & $<1$ & & & & & & & & \\
\hline \multirow{2}{*}{\multicolumn{21}{|c|}{$\begin{array}{l}\text { FAMILY LEPADELLIDAE } \\
\text { Lepadella patella (Müller, 1773) }\end{array}$}} \\
\hline & & & & & & & & & & & & & & & & & & & & \\
\hline \multicolumn{21}{|l|}{ FAMILY NOTOMMATIDAE } \\
\hline \multicolumn{21}{|l|}{ Cephalodella forficata (Ehrenberg, 1832) } \\
\hline \multicolumn{21}{|l|}{ Cephalodella sterea sterea (Gosse, 1887) } \\
\hline Resticula gelida (Harring \& Myers, 1922) & & & & & & & & & & & & & & & & & & & & \\
\hline TOTAL NUMBER OF TAXA & 3 & 2 & 1 & 1 & 1 & 2 & 1 & 1 & 2 & 1 & 1 & 2 & 1 & 1 & 1 & 1 & 6 & 1 & 1 & 3 \\
\hline TOTAL ABUNDANCE, IND $\cdot \mathrm{L}^{-1}$ & - & - & - & - & - & - & - & - & - & - & - & - & - & - & - & - & - & $<1$ & 2 & - \\
\hline
\end{tabular}




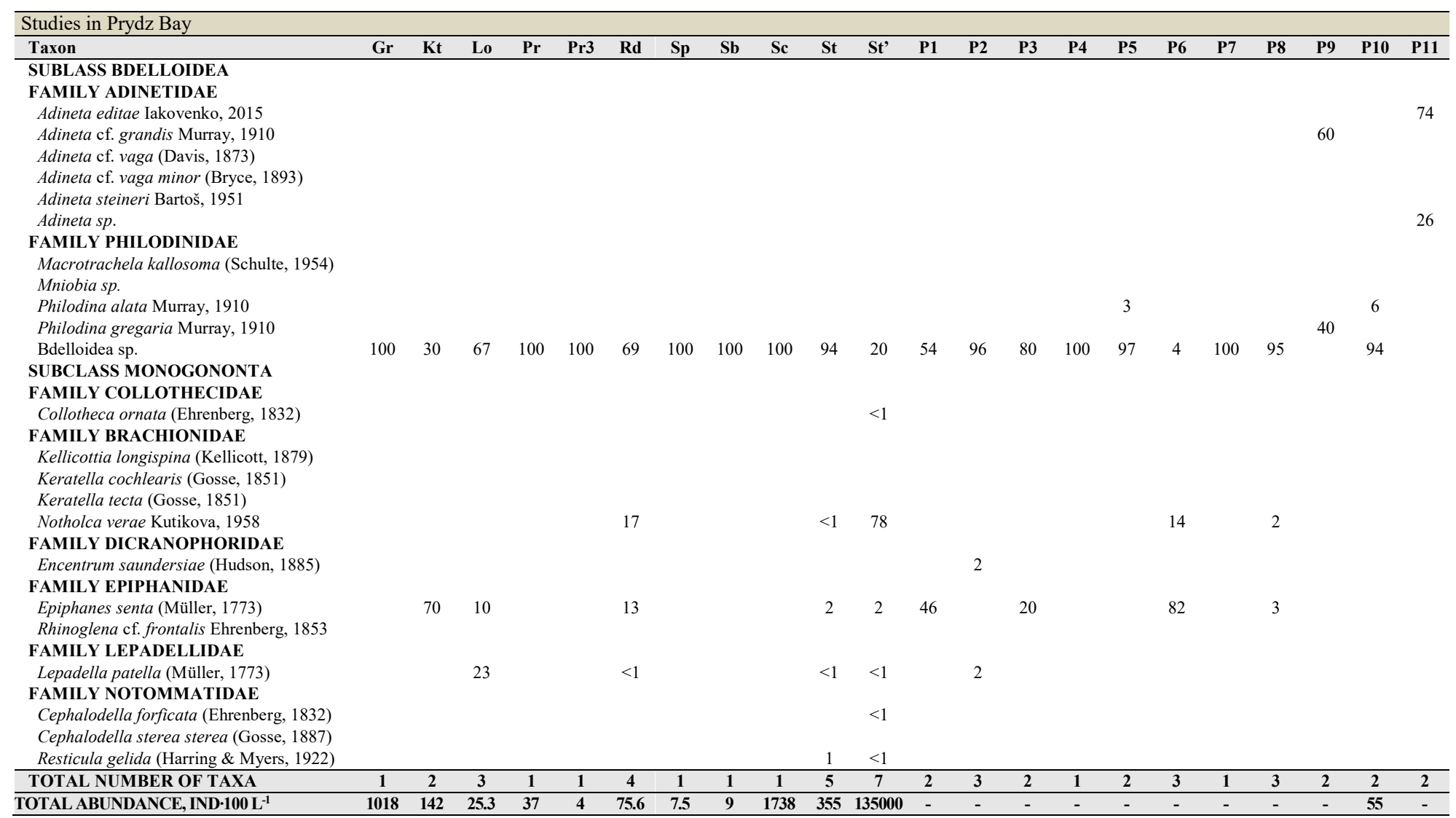


Table 4. Comparison of the data obtained with the earlier published evidences.

\begin{tabular}{|c|c|c|}
\hline Taxon & $\begin{array}{c}\text { References in which the taxa } \\
\text { are listed } \dagger\end{array}$ & $\begin{array}{l}\text { Regions outside Antarctica } \\
\text { where the taxa are found in } \\
\text { (according to [16]) }\end{array}$ \\
\hline \multicolumn{3}{|l|}{ SUBCLASS BDELLOIDEA } \\
\hline \multicolumn{3}{|l|}{ FAMILY ADINETIDAE } \\
\hline Adineta editae Iakovenko, 1893 & $6,10,18,19,22 \ddagger$ & - \\
\hline Adineta cf. grandis Murray, 1910 & $4,7,14,15,20,23$ & Afr, Pal (?) $\S$ \\
\hline Adineta steineri Bartoš, 1951 & 18,19 & Aus, Nea, Neo, Pal \\
\hline Adineta $\mathrm{cf}$ vaga vaga (Davis, 1873) & $10,14,18,19,24$ & Afr, Aus, Ind, Nea, Neo, Pal \\
\hline Adineta $\mathrm{cf}$ vaga minor (Bryce, 1893) & - & Aus, Ind, Nea, Pal \\
\hline \multicolumn{3}{|l|}{ FAMILY PHILODINIDAE } \\
\hline Macrotrachela kallosoma (Schulte, 1954) & - & Aus, Neo, Pal \\
\hline Philodina alata Murray, 1910 & $2,5,7,9,11,12,14,24$ & - \\
\hline Philodina gregaria Murray, 1910 & $1,2,4,7,8,14,15,21,24$ & - \\
\hline \multicolumn{3}{|l|}{ SUBCLASS MONOGONONTA } \\
\hline \multicolumn{3}{|l|}{ FAMILY COLLOTHECIDAE } \\
\hline Collotheca ornata (Ehrenberg, 1832) & $1,4,5,7,11,12,14$ & Cosmopolitan \\
\hline \multicolumn{3}{|l|}{ FAMILY BRACHIONIDAE } \\
\hline Kellicottia longispina (Kellicott, 1879) & 9 & Afr, Ind, Nea, Neo, Pal \\
\hline Keratella cochlearis (Gosse, 1851) & $5,9,13$ & Afr, Aus, Ind, Nea, Neo, Pal \\
\hline Keratella tecta (Gosse, 1851) & - & Afr, Aus, Ind, Nea, Neo, Pal \\
\hline Notholca verae Kutikova, 1958 & $3(?), 8,11,12$ & - \\
\hline \multicolumn{3}{|l|}{ FAMILY DICRANOPHORIDAE } \\
\hline Encentrum saundersiae (Hudson, 1885) & - & Aus, Nea, Neo, Pal \\
\hline \multicolumn{3}{|l|}{ FAMILY EPIPHANIDAE } \\
\hline Epiphanes senta (Müller, 1773) & $1,4,5,7,11,12,14,23$ & Cosmopolitan \\
\hline Rhinoglena cf. frontalis Ehrenberg, 1853 & - & Aus, Ind, Nea, Pal \\
\hline \multicolumn{3}{|l|}{ FAMILY LEPADELLIDAE } \\
\hline Lepadella patella (Müller, 1773) & $4,5,8,11-13,15,17,22$ & Cosmopolitan \\
\hline \multicolumn{3}{|l|}{ FAMILY NOTOMMATIDAE } \\
\hline Cephalodella forficata (Ehrenberg, 1832) & - & Aus, Ind, Nea, Neo, Ocn, Pal \\
\hline Cephalodella sterea (Gosse, 1887) & 4,12 & Aus, Ind, Nea, Neo, Ocn, Pal \\
\hline Resticula gelida (Harring \& Myers, 1922) & 4,5 & Aus, Nea, Neo, Pal \\
\hline
\end{tabular}

$\dagger$ We have taken into account East Antarctic regions only - foremost, localities in both Enderby Land (Thala Hills) and Prydz Bay (Larsemann Hills); as well as other regions of this part of continent, viz. Princess Elizabeth Land (Vestfold Hills), Wilkes Land (Wilkes station, Bunger Hills, Knox coast), Queen Mary Land (Obruchev Hills, Huswell Island), Victoria Land (Eastern coast of Ross Sea, Ross Peninsula, Ross Ice Shelf, McMurdo Dry Valleys and McMurdo Sound area, Darvin Glacier and other localities), Dronning Maud Land (Langhovde Hills, Schirmacher oasis, the set of nunataks). Numerous data related to rotifer fauna in territories of the western part of continent as well as Maritime Antarctica and Subantarctica (Kerguelen, Malvinas, etc.) are not included in the present review.

\$ All references related to Adineta gracilis are given here (see text)

$\S$ Designations of biogeographic realms: Afr - Africotropical, Aus - Australasian, Ind - Indomalayan (Oriental), Nea - Nearctic, Neo - Neotropical, Ocn - Oceanian (Pacific); Pal - Palearctic.

References: 1 - Armitage \& House (1962); 2 - Chatey (1981); 3 - Cromer at al. (2006); 4 -Dartnall (1995), 5 Dartnall (2000); 6 - Donner (1972); 7 - Dougherty \& Harris (1963); 8 - Everitt (1981); 9 - Hansson et al. (2012); 10 - Iakovenko et al. (2015); 11 - Korotkevich (1958); 12 - Kutikova (1958); 13 - Kutikova (1991); 14 - Murray (1910); 15 - Opaliński (1972); 16 - Segers (2008); 17 - Sharov et al. (2015); 18 - Sohlenius et al. (1996); 19 Sohlenius \& Bostrőm (2005); 20 - Smykla et al. (2010); 21 - Spur (1975); 22 - Sudzuki (1964); 23 - Suren (1990); 24 - Webster \& Brown (2010).

Fontaneto et al. (2015b) demonstrated the inverse character of species diversity gradients touching both rotifer groups in Antarctica - with rising of the absolute latitude up to $75^{\circ} \mathrm{S}$ the number of monogonont species was decreasing, while that of bdelloids was increasing. In other words, in continental Antarctica i.e. in a high-latitude region with harsh climate the main centers of meiobiodiversity are different terrestrial organic substrates that bdelloids willingly inhabit in contradistinction to inland waters (meltwater ponds and lakes) with very poor species richness 
of monogonont rotifers. The described phenomenon shows that our results over Bdelloidea are still preliminary and determines the investigation of rotifers in Antarctic terrestrial habitats as main prospective aim of further studies.

The analysis of rotifer diversity has shown the dominance of common taxa for Antarctica, which were quite expected to find: Epiphanes senta (Müller, 1773), Lepadella patella (Müller, 1773), and some others. Some of them are cosmopolitans (Table 4). On the contrary, there were found several species and subspecies, which can be regarded as rare or even new for East Antarctica. Firstly we can mention Collotheca ornata (Ehrenberg, 1832). Many authors (Murray 1910, Korotkevich 1958, Kutikova 1958, Dougherty \& Harris 1963, Dartnall 1995, 2000) declare the presence of Collotheca ornata cornuta (Dobie, 1849) in waters of Antarctica. The presence of Collotheca ornata (not cornuta subspecies) is also pointed, but much less (Armitage \& House 1962). Some species among new ones for East Antarctica were also registered in other regions either of the continent or a biogeographical realm (Table 4). For example, Dartnall and Hollowday (1985) point the presence of Cephalodella forficata (Ehrenberg, 1832) in samples collected at Signy Island (South Orkney Islands, Subantarctica); Kutikova (1991) points Macrotrachela kallosoma (Schulte, 1954) in Falkland Islands. The third one, Rhinoglena frontalis Ehrenberg, 1853, was found in the number of Subantarctic territories: Heard Island (Dartnall 1995b), Kerguelen (De Smet 2001), and Macquarie Island (Dartnall 1993, Dartnall et al. 2005). Finally, Encentrum saundersiae (Hudson, 1885) and Keratella tecta (Gosse, 1851) seem to be found in whole Antarctic region in fact firstly. Furthermore, Adineta vaga minor Bryce, 1893 according to literature data was not recorded in Antarctica earlier.

The problem of Antarctic endemic rotifers (bdelloids in the first place) is a real urgent issue. Previously declared cosmopolite nature of these animals is now being questioned (VellascoCastrillon et al. 2014; Iakovenko et al. 2015); existing of many rotifer species, unique for remote territories, well correlates with the modern ideas concerning the abundance and occurrence of meiofauna in general as well, viz. 'a very big number of rare species' (Curini-Galletti et al. 2012, Fonseca et al. 2014, Fontaneto et al. 2015a and others). Thus, the set of endemic bdelloid species - Philodina alata, Ph. antarctica Murray, 1910, Ph. gregaria Murray, 1910, Adineta grandis Murray, 1910 (questionable - see Segers 2007), and some others - have been revealed for Antarctica since very first studies (Murray 1910). As results of more recent works (Kutikova 1958, De Smet \& Gibson 200), some endemic monogononts have become known - Notholca verae Kutikova, 1958, Rhinoglena kutikovae De Smet, 2008. There were found several endemics in our study: already mentioned Adineta grandis, Notholca verae, Philodina alata, Ph. gregaria; also one another recently described species - Adineta editae Iakovenko, 2015. Notwithstanding, cosmopolitan species together with species which are widely distributed including Southern Hemisphere consist more than $50 \%$ of all recorded species (Table 4).

\section{ACKNOWLEDGEMENTS}

We would like to thank all members of the $1^{\text {st }}, 2 \mathrm{nd}, 4$ th, 5th, 6sth, 8th and 9th BAE for the feasible assistance in conducting the collection of the material; head and members of Russian Antarctic expeditions for giving the opportunity for the Belarusian polar explorers to live and work on several Russian Antarctic stations; crew of the scientific and research ship 'Akademik Fyodorov'. In addition, our thanks are due to $\mathrm{PhD}$ Natalia S. Iakovenko (I. I. Schmalgausen Institute of Zoology, National Academy of Sciences of Ukraine; University of Ostrava, Czech Republic) for helping the bdelloid identification and essential advices.

The Government Program 'Monitoring the Earth's Polar Regions, the creation of the Belarusian Antarctic station and the maintenance of the polar expeditions in 2016-2020 years' supported the work. 


\section{REFERENCES}

Adams B. J., Bardgett R. D., Ayres C., Wall D. H., Aislabie J., Bamforth S., Bargagli R. \& Cary C. 2006. Diversity and distribution of Victoria Land biota. Soil Biology and Biochemistry 38: 3003-3018.

ARMitAge K.B. \& House H.B. 1962. A limnological reconnaissance in the area of McMurdo Sound, Antarctica. Limnology and Oceanography 7: 36-41.

BARTOŠ E. 1951. The Czechoslovak Rotatoria of the order Bdelloidea. Věstnik Československé Zoologické Společnosti 15: $241-500$.

BRYCE D. 1893. On the Adinetidae, with description of a new species. The Journal of the Quekett Microscopical Club, Ser. 2. 5: $146-151$.

CONVEY P. 2010. Terrestrial biodiversity in Antarctica - Recent advances and future challenges. Polar Science 4: $135-147$.

CONVEY P., CHOWn S. L., ClARKE A. et al. 2014. The spatial structure of Antarctic biodiversity. Ecological Monographs 84 (2): 203-244.

Cromer L., GibSon J.A.E., Swadling K.M. \& HodgSon D.A. 2006. Evidence for a lacustrine faunal refuge in the Larsemann Hills, East Antarctica, during the last glacial maximum. Journal of Biogeography 33: 1314-1323. DOI: http://dx.doi.org/10.1111/j.1365-2699.2006.01490.x

Curini-Galletti M., Artois T., Delogu V., De Smet W. H., Fontaneto D., Jondelius U., Leasi F., Martínez A., Meyer-Wachsmuth I., Nilsson K. S., Tongiorgi P., Worsaae K., M. Antonio Todaro A. 2012. Patterns of diversity in soft-bodied meiofauna: dispersal ability and body size matter. PLoS ONE 7 (3): e33801. DOI: https://doi.org/10.1371/journal.pone.0033801

DARTNALl H .J. G. 1983. Rotifers of the Antarctic and subantarctic. Hydrobiologia 104: 57-60.

DARTNALl H. J. G. 1993. The rotifers of Macquarie Island. ANARE Research Notes 89: 1-41.

DARTNALl H. J. G. 1995. Rotifers, and other aquatic invertebrates, from the Larsemann Hills, Antarctica. Papers and Proceedings of the Royal Society of Tasmania 129: 17-23.

DARTNALl H. J. G. 1995b. The rotifers of Heard Island: preliminary survey, with notes on other freshwater groups. Papers and Proceedings of the Royal Society of Tasmania 129: 17-23.

DARTNALl H. J. G. 2000. A Limnological Reconnaissance of the Vestfold Hills. ANARE Reports Australian Antarctic Division 141: 1-55.

Dartnall H. J. G. \& Hollowday E.D. 1985. Antarctic rotifers. British Antarctic Survey, Scientific Reports 100: 46.

Dartnall H. J. G., Hollwedel H. \& De PaGgi J. C. 2005. The freshwater fauna of Macquarie Island, including a redescription of the endemic water-flea Daphnia gelida (Brady) (Anomopoda: Crustacea). Polar Biology 28: 922-939.

DAVIS H. 1873. A new Callidina; with the results of experiments on the desiccation of rotifers. The monthly microscopical journal: transactions of the Royal Microscopical Society, and record of histological research at home and abroad by Henry Lawson. London 9: 201-209.

De PAGGi S. J. \& Koste W. 1984. Checklist of the rotifers recorded from Antarctic and Subantarctic areas. Senckenbergiana Biologica 65: 169-178.

De Smet W. H. \& GiBson J. A. E. 2008. Rhinoglena kutikovae n. sp. (Rotifera: Monogononta: Epiphanidae) from the Bunger Hills, East Antarctica: a probable relict species that survived quaternary glaciations. Polar Biology 31: 595603. DOI: http://dx.doi.org/10.1007/s00300-007-0393-9

De SMET W. H. \& Pourriot R. 1997. Guides to Identification of the Microinvertebrates of the Continental Waters of the World. 12. Rotifera. Volume 5. The Dicranophoridae (Monogononta). The Ituridae (Monogononta) Hague: SPB Academic Publishing, 334 pp.

DONNER J. 1965. Ordnung Bdelloidea (Rotatoria, Rädertiere). Bestimmungsbücher zur Bodenfauna Europas, 6. 1-297. Berlin: Akademie.

DONNER J. 1972. Report on the finding of Rotifera (Rotatoria) from Antarctica. Polskie Archiwum Hydrobiologii 19 (3): $251-252$.

Dougherty E. C. \& Harris L. G. 1963. Antarctic Micrometazoa: fresh-water species in the McMurdo Sound Area. Science 140: 497-498.

EHRENBERG C. G. 1832. Über die Entwicklung und Lebensdauer der Infusionstiere, nebst ferneren Beiträgen zu einer Vergleichung ihrer organischen Systeme. Abhandlungen der Königlichen Akademie der Wissenschaften zu Berlin 1831: $1-154$.

EHRENBERG C. G. 1853. Über die neuerlich bei Berlin vorgekommen neuen Formen des mikroskopischen Lebens. Bericht über die zur Bekanntmachung geeigneten Verhandlungen der Konigl. Preuss. Akademie der Wissenschaften zu Berlin: 183-194.

EVERITT D.A. 1981. An ecological study of an Antarctic freshwater pool with particular reference to Tardigrada and Rotifera. Hydrobiologia 83: 225-237.

FontAneto D., Flot J. F. \& TANG C. Q. 2015. Guidelines for DNA taxonomy, with a focus on the meiofauna. Marine Biodiversity 45 (3): 433-451. DOI: http://dx.doi.org/10.1007/s12526-015-0319-7

Fontaneto D., Kaya M., Herniou E.A. \& Barraclough T.G. 2009. Extreme levels of hidden diversity in microscopic animals (Rotifera) revealed by DNA taxonomy. Molecular Phylogeny and Evolution 53: 182-189.

Fontaneto D., IAKOVEnKo N. \& DE SMET W. 2015. Diversity gradients of rotifer species richness in Antarctica. Hydrobiologia 761 (1): 235-248. DOI: http://dx.doi.org/10.1007/s10750-015-2258-5 
Fontaneto D., Barraclough T. G., Chen K., Ricci C. \& Herniou E. A. 2008. Molecular evidence for broad-scale distributions in bdelloid rotifers: everything is not everywhere but most things are very wide-spread. Molecular Ecology 17: 3136-3146. DOI: http://dx.doi.org/10.1111/j.1365-294X.2008.03806.x

Fonseca V.G., CARVAlho G.R., Nichols B. [ET AL.] 2014. Metagenetic analysis of patterns of distribution and diversity of marine meiobenthic eukaryotes. Global Ecology \& Biogeography 23: 1293-1302. DOI: http://dx.doi.org/10.1111/geb.12223

Gosse P. H. 1851. A catalogue of Rotifera found in Britain, with description of five new genera and thirty-two new species. The Annals and magazine of natural history; zoology, botany, and geology, ser. 2, 8: 197-203.

Gosse P. H. 1887. Twenty-four new species of Rotifera. Journal of the Royal Microscopical Society 1887 (1): Transactions of Society 1: 1-7, pl. I \& II.

HansSOn L. A., Hylander S., DARTNAll H. J. G., Lidström S. \& SvensSOn J. E. 2012. High zooplankton diversity in the extreme environments of the McMurdo Dry Valley lakes, Antarctica. Antarctic Science 24: 131-138. doi: http://dx.doi.org/10.1017/S095410201100071X

Harring H. K. \& MYers F. J. 1922. The Rotifer Fauna of Wisconsin, Transactions of the Wisconsin Academy of Sciences, Arts, and Letters 20: 553-662.

HuDSON C. T. 1885. On four new species of the genus Floscularia and five other new species of Rotifera. Journal of the Royal Microscopical. Ser. 2, 5 (4): Transactions of Society 13: 608-614, pl. XII.

IAKOVEnKo N. S., KAŠPAROVÁ E., PleWKa M. \& JANKO K. 2013. Otostephanos (Rotifera, Bdelloidea, Habrotrochidae) with the description of two new species. Systematics and Biodiversity 11 (4): 477-494. DOI: https://doi.org/10.1080/14772000.2013.857737

Iakovenko N. S., Smykla J., Convey P., KašParová E., Kozeretska I. A., Trokhymets V., Dykyy I., PlewKa M., DevetTer M., Duris Z. \& JANKO K. 2015. Antarctic bdelloid rotifers: diversity, endemism and evolution. Hydrobiologia 761 (1): 5-43. doi: http://dx.doi.org/10.1007/s10750-015-2463-2

JANSON F. O. F. 1893. Versuch einer Übersicht über die Rotatorien-Famile der Philodinaeen. Inaugural-Dissertation zur Erlangung der Doktorwürde bei der Hohen Philosophischen Fakultät der Universität Marburg engereicht von Otto Janson aus Bremen. Marburg, Oscar Erhardt, 86 pp. +5 pl.

KeLLicotT D. S. 1879. A new rotifer. The American Journal of Microscopy and Popular Science 4: 19-20.

KorotKevich V. S. 1958. Concerning the population of water bodies in the oases of East Antarctica. Soviet Antarctic Expedition Information Bulletin 3: 91-98. [In Russian]

KuTIKOVA L. A. 1958. A new rotifer from the Antarctic. Soviet Antarctic Expedition Information Bulletin 2: 45-46. [In Russian]

Kutikova L. A. 1958. Rotifers from the coast of East Antarctica. Soviet Antarctic Expedition Information Bulletin 3: 162. [In Russian].

KuTIKova L. A. 1970. Rotifers in the fauna of USSR. Part V. Subclass Eurotatoria (Orders Ploimida, Monimotrochida, Paedotrochida). Nauka, Leningrad, 744 pp. [In Russian].

KuTIKOVA L. A. 1991. Rotifers of the inland waters of East Antarctica. Soviet Antarctic Expedition Information Bulletin 116: 87-99. [In Russian].

Kutikova L. A. 2005. Bdelloid rotifers in the fauna of Russia. Moscow: KMK Scientific Press, 315 pp. [In Russian]

Meksuwan P., Pholpunthin P. \& Segers H. 2013 The Collothecidae (Rotifera, Collothecacea) of Thailand, with the description of a new species and an illustrated key to the Southeast Asian fauna. Zookeys 315: 1-16. DOI: http://dx.doi.org/10.3897/zookeys.313.5330.

MuRRAY J. 1910. British Antarctic Expedition, 1907-9, under the command of Sir E. H. Shackleton, c.v.o. Reports of the Scientific Investigations, London, 1 (Biology, 3): 41-73.

MÜLLER O. F. 1773. Vermium terrestrium et fluviatilium, seu animalium infusorium, helminthicorum et testaceorum, non marinorum, succincta historia. Havniae et Lipsiae 1: 1-135. [In Latin]

Nogrady Th., Poirrot R. \& SegErs H. 1995. Guides to Identification of the Microinvertebrates of the Continental Waters of the World. 8. Rotifera. Volume 3. The Notommatidae. The Scaridiidae. SPB Academic Publishing. Hague, 248 pp.

OPALIŃSKI K.W. 1972. Flora and fauna in freshwater bodies of the Thala Hills Oasis (Enderby Land, Eastern Antarctica). Polskie Archiwum Hydrobiologii 19: 383-398.

RiCHTERS F. 1904. Vorläufiger Bericht über die antarktische Moosfauna. Verhandlungen der Deutschen Zoologischen Gesellschaft 24: 236-239.

RiCHTERS F. 1907. Die Fauna der Moosrasen des Gaussbergs und einiger südlicher Inseln. Deutsche Südpolar Expedition 1901-1903 9: 258-302.

JersabeK C. D. \& LeITNER M. F. 2013: The Rotifer World Catalog. World Wide Web electronic publication. http://www.rotifera.hausdernatur.at/, accessed (DD.MM.YYYY = date of access).

RUSSELL C. R. 1959. Rotifera. B.A.N.Z. Antarctic research expedition 1929-1931. Reports 8 (3): 83-87.

SCHULTE H. 1954. Beiträge zur Ökologie und Systematik der Bodenrotatorien. Zoologische Jahrbücher (Systematik) 82 (6): 497-654.

SCHWOERBEL J. 1972. Methods of hydrobiology. Freshwater ecology. $1^{\text {st }}$ ed. Pergamon Press, 210 pp.

SEgERS H. 2007. Annotated checklist of the rotifers (Phylum Rotifera), with notes on nomenclature, taxonomy and distribution. Zootaxa 1564: 1-104. 
Sharov A. N., Berezina N. A. \& Tolstikov A. V. 2015. Life under ice in the perennial ice-covered Lake Glubokoe in Summer (Eastern Antarctica). Lakes and reservoirs: research and management 20: 120-127. DOI: http://dx.doi.org/10.1111//re.12093

SHIEL R. J. 1995. A guide to identification of rotifers, cladocerans and copepods from Australian inland waters. The Murray-Darling Freshwater Research Centre, Albury, 145 pp.

Shtarkman Y. M., Koçer Z. A., Edgar R., Veerapaneni R. S., D’Elia T., Morris P. F. \& Rogers S. O. 2013. Subglacial Lake Vostok (Antarctica) accretion ice contains a diverse set of sequences from aquatic, marine and sediment-inhabiting bacteria and eukarya. PLoS ONE 8: 1-13. DOI: https://doi.org/10.1371/journal.pone.0067221

Smykla J., Porazinski D. L., IAKovenko N., Janko K., Weiner W. M., Niedbala W. \& DreWniK M. 2010. Studies on Antarctic soil invertebrates: preliminary data on rotifers (Rotatoria), with notes on other taxa from Edmonson Point (Northern Victoria Land, Continental Antarctic). Acta Societatis Zoologicae Bohemicae 74: 135-140.

SOHLENIUS B. \& BOSTRÖM S. 2005. The geographic distribution of metazoan microfauna on East Antarctic nunataks. Polar Biology 28: 439-448. doi: http://dx.doi.org/10.1007/s00300-004-0708-z

SOHLENIUS B., BOSTRÖM S. \& HIRSCHFELDER A. 1995. Nematodes, rotifers and tardigrades from nunataks in Dronning Maud Land, East Antarctica. Polar Biology 15: 51-56.

SpurR B. 1975. Limnology of Bird Pond, Ross Island, Antarctica. New Zealand Journal of Marine and Freshwater Research 9: 547-562.

SUDZUKI M. 1964. On the Microfauna of the Antarctic Region : I. Moss-water community at Langhovde. Tokyo, Japan: Polar Section, National Science Museum. JARE scientific reports. Ser. E, Biology, 1956-1962, No. 19, 41 pp.

SUDZUKI M. 1979. On the microfauna of the Antarctic region. III. Microbiota of the terrestrial interstices. Proceedings of the Symposium on Terrestrial Ecosystem in the Syowa Station area. Memoirs of National Institute of Polar Research 11: 104-126.

SUDZUKi M. 1988. Comments on the Antarctic Rotifera. Hydrobiologia 165: 89-96.

SUREN A. 1990. Microfauna associated with algal mats in meltwater ponds of the Ross Ice Shelf. Polar Biology 10: 329 335. DOI: http://dx.doi.org/10.1007/BF00237819

Thomas C. W. 1965. On populations in Antarctic meltwater pools. Pacific Science 19: 515-521.

Thomas C. W. 1972. Two species of Antarctic rotifers. Antarctic Journal of the United States 7: 186-187.

Velasco-Castrillón A., Gibson J. A. E. \& Stevens M. I. 2014. A review of current Antarctic limno-terrestrial microfauna. Polar Biology 37: 1517-1531. DOI: http://dx.doi.org/10.1007/s00300-014-1544-4

Velasco-Castrillón A., PAge T. J., Gibson J. A. E. \& Stevens M. I. 2014. Surprisingly high levels of biodiversity and endemism amongst Antarctic rotifers uncovered with mitochondrial DNA. Biodiversity 15: 1-13. DOI: http://dx.doi.org/10.1080/14888386.2014.930717

Webster-Brown J., Gall M., GiBson J. A. E., Wood S. \& HaweS I. 2010. The biogeochemistry of meltwaterwater habitats in the Darwin Glacier region (80 S), Victoria Land, Antarctica. Antarctic Science 22: 646-661. DOI: http://dx.doi.org/10.1017/S0954102010000787

\section{STRESZCZENIE}

\section{[Wrotki (Rotifera) wód śródlądowych i środowisk naziemnych oaz Wschodniej Antarktyki (Enderby Land and Prydz Bay)]}

Artykuł dotyczy raportu na temat fauny wrotków (Rotifera) kontynentalnej Wschodniej Antarktyki, nadal słabo zbadanej. W środowiskach wodnych i naziemnych znaleziono w sumie 20 gatunków tych mikroskopijnych bezkręgowców. Wykazaliśmy występownie 12 gaunków z podklasy Monogononta oraz 8 gatunków z podklasy Bdelloidea. Analiza danych wskazuje na bardzo niską różnorodność taksonomiczną wrotków znalezionych w planktonie ponad 50 różnych jezior i wytopisk. Z drugiej strony, dość pobieżny przegląd środowisk naziemnych pozwolił ujawnić aż 7 gatunków wrotków (wszystkie należące do Bdelloidea). Większość stwierdzonych gatunków jest raczej pospolitymi kosmopolitami (Collotheca ornata, Epiphanes senta czy Lepadella patella) lub antarktycznymi endemitami (Notholca verae, Philodina alata lub Ph. gregaria). Mimo to, niektóre gatunki mogą być uważane za nowe stwierdzenia dla Wschodniej Antarktyki (jak Encentrum saundersiae, Keratella tecta czy Macrotrachela kallosoma). Przedyskutowano biogeograficzne osobliwości antarktycznych wrotków. Specjalną uwagę zwrócono na taksonomię gatunków z rodzaju Adineta (podklasa Bdelloidea) ujawnionych w środowiskach naziemnych. 